\title{
Impact of long-term viral suppression in CD4+ recovery of HIV-children on Highly Active Antiretroviral Therapy
} Salvador Resino*1, Rosa Resino1, Juan A Leon ${ }^{2}$, José M Bellon', Pablo Martin-Fontelos ${ }^{3}$, Jose T Ramos ${ }^{4}$, Dolores Gurbindo-Gutierrez ${ }^{5}$, Maria I de Jose ${ }^{6}$, Luis Ciria ${ }^{7}$ and Maria A Muñoz-Fernandez ${ }^{1}$

Address: ${ }^{1}$ Laboratorio de Inmuno-Biología Molecular, Hospital General Universitario "Gregorio Marañón", Madrid. Spain, ${ }^{2}$ Servicio de PediatríaInfecciosas; Hospital Universitario "Virgen de Rocío", Sevilla. Spain, ${ }^{3}$ Servicio de Pediatría-Infecciosas; Hospital Universitario "Carlos III", Madrid. Spain, ${ }^{4}$ Servicio de Inmuno-Pediatría; Hospital Universitario "12 de Octubre", Madrid. Spain, ${ }^{5}$ Servicio de Inmuno-Pediatría; Hospital General Universitario "Gregorio Marañón", Madrid. Spain, ${ }^{6}$ Servicio de Inmuno-Pediatría; Hospital Universitario "La Paz", Madrid. Spain and 7 Servicio de Pediatría-Infecciosas; Hospital Universitario "Niño Jesús". Madrid, Spain

Email: Salvador Resino* - sresino.hgugm@salud.madrid.org; Rosa Resino - rosaresino@hotmail.com; Juan A Leon - jaleon@hotmail.com; José M Bellon - jbellon.hgugm@salud.madrid.org; Pablo Martin-Fontelos - pmfontelos@eresmas.com;

Jose T Ramos - jtramos.h12oct@salud.madrid.es; Dolores Gurbindo-Gutierrez - mdgurbindo.hgugm@salud.madrid.org; Maria I de Jose - mijose.hlapaz@salud.madrid.org; Luis Ciria - luisciria@eresmas.com; Maria A Muñoz-

Fernandez - inmunobiologia.hgugm@salud.madrid.org

* Corresponding author

Published: 24 January 2006

BMC Infectious Diseases 2006, 6:10 doi:10.1/86/147/-2334-6-10
Received: 12 July 2005

Accepted: 24 January 2006

This article is available from: http://www.biomedcentral.com/I47/-2334/6/10

(C) 2006 Resino et al; licensee BioMed Central Ltd.

This is an Open Access article distributed under the terms of the Creative Commons Attribution License (http://creativecommons.org/licenses/by/2.0), which permits unrestricted use, distribution, and reproduction in any medium, provided the original work is properly cited.

\begin{abstract}
Background: The effects of HAART may differ between children and adults because children have a developing immune system, and the long-term immunological outcome in HIV-infected children on HAART is not well-known. A major aim of our study was to determine CD4+ evolution associated with long-term VL control during 4 years of observation on HAART.

Methods: We carried out a retrospective study on a cohort of 160 vertically HIV-infected children. It was carried out from 1996 to 2004 in six large Spanish pediatric referral hospitals. We compared 33 children who had long-term VL suppression ( $\mathrm{VL} \leq 400$ copies $/ \mathrm{ml}$ ) in the first 12 months of follow-up and maintained that level throughout follow-up (Responders-group), and 127 children with persistently detectable VL in spite of ART switches (Non-Responders-group).

Results: We observed a quick initial and significant increase in $\mathrm{CD}^{+}$counts from the baseline to 12 months on HAART in both groups $(\mathrm{p}<0.0 \mathrm{I})$. The Non-Responders group sustained CD4+ increases and most of these children maintained high $C D 4^{+}$level counts $(\geq 25 \%)$. The NonResponders group reached a plateau between $26 \%$ and $27 \% \mathrm{CD}^{+}$at the first 12 months of followup that remained stable during the following 3 years. However, the Responders group reached a plateau between $30 \%$ and $32 \% \mathrm{CD}^{+}$at 24,36 and 48 months of follow-up. We found that the Responders group had higher $\mathrm{CD} 4^{+}$count values and higher percentages of children with $C D 4^{+} \geq 25 \%$ than the Non-Responders group $(p<0.05)$ after month 12 .
\end{abstract}

Conclusion: Long-term VL suppression in turn induces large beneficial effects in immunological responses. However, it is not indispensable to recover CD4+ levels. 


\section{Background}

The efficacy of highly active antiretroviral therapy (HAART) is shown by the fact that many patients achieve suppression of viral load (VL) below the limits of detection (uVL) along with an increase of $\mathrm{CD}^{+} \mathrm{T}$-lymphocytes $\left(\mathrm{CD} 4{ }^{+}\right)[1,2]$, resulting in a good clinical outcome $[3,4]$. Immediate suppression of VL is often achieved with HAART, but long-term suppression of VL is not always feasible [1]. Children receiving treatment usually have higher VL and lower virologic response rates than adults $[1,5]$. Moreover, the effects of HAART may differ between children and adults because children have a developing immune system, but the long-term immunological outcome in HIV-infected children on HAART is not wellknown [6]. A major aim of our study was to determine CD4+ evolution associated with long-term VL control.

\section{Methods}

\section{Population and study design}

A retrospective study on a cohort of 160 vertically HIVinfected children has been carried out from 1996 to 2004 in six large Spanish pediatric referral hospitals. The inclusion criteria of HIV-1-infected children were the following: a) starting HAART with protease inhibitor (PI) or non-nucleoside analogue HIV-1 reverse transcriptase inhibitor (NNRTI); b) 4 years of follow-up after starting HAART; c) VL >5,000 copies/ml at entry to the study, d) older than 6 months of age at entry. From an initial cohort of 200 vertically HIV-1-infected children with at least 4 years on HAART, 40 children were excluded because they had $\mathrm{VL}<5,000$ copies/ml (30 children), no data regarding VL ( 1 child), or they were less than 6 months old ( 9 children). Therefore, 160 out $200 \mathrm{HIV}$-infected children fulfilled the criteria of inclusion and were enrolled in the present retrospective study.

This study was approved by the Ethical Committees of all hospitals involved. Clinical classification was based on the 1994 revised guidelines of the Centers for Disease Control (CDC). The children were monitored at least every 3 months with repeated interviews, physical examinations, and blood sample collection. There was not an uniform approach regarding antiretroviral treatment. Instead, each pediatrician administered the appropriate antiretroviral therapy (ART) regimen and changed the drugs according to his/her interpretation of the child's data and following international guidelines. The adherence of antiretroviral drugs was measured by each pedia-

Table I: Characteristics of clinical, immunological, and virological parameters of vertically HIV-I-infected children.

\begin{tabular}{|c|c|c|}
\hline & Responders & Non-Responders \\
\hline N. of HIV-infected children & 33 & 127 \\
\hline Age (years) ${ }^{(a)}$ & $5.9(1.2 ; 15.7)$ & $5.7(0.5 ; 14.9)$ \\
\hline Male (b) & $17(51.5 \%)$ & $58(45.6 \%)$ \\
\hline AIDS diagnosis (CDC) ${ }^{(b)}$ & $13(39.3 \%)$ & $58(45.6 \%)$ \\
\hline \multicolumn{3}{|l|}{ Current immunological category $(\mathrm{b})$} \\
\hline$>25 \% \mathrm{CD}^{+}$ & $8(24.2 \%)$ & $40(31.4 \%)$ \\
\hline $15 \%-25 \% \mathrm{CD}^{+}$ & $9(27.2 \%)$ & 31 (24.4\%) \\
\hline$<15 \% \mathrm{CD}^{+}$ & $16(48.4 \%)$ & 52 (40.9\%) \\
\hline \multicolumn{3}{|l|}{ Immunological parameters (a) } \\
\hline$\% \mathrm{CD}^{+}$ & $12(0.1 ; 35)$ & $18(0.1 ; 52)$ \\
\hline $\mathrm{CD}^{+} / \mu \mathrm{L}$ & $333(4 ; 1207)$ & $440(1 ; 2620)$ \\
\hline$\% \mathrm{CD}^{+}$ & $49(22.1 ; 82)$ & $47(13 ; 74.6)$ \\
\hline $\mathrm{CD}^{+} / \mu \mathrm{L}$ & $927(238 ; 3763)$ & $1006(17 ; 6466)$ \\
\hline \multicolumn{3}{|l|}{ Virological characteristics } \\
\hline $\log _{10} V L($ copies/mL) & $4.8(3.7 ; 6.4)$ & $4.8(3.7 ; 6.5)$ \\
\hline $\mathrm{VL} \leq 10,000$ copies $/ \mathrm{mL}$ & $6(18.1 \%)$ & $8(6.2 \%)$ \\
\hline VL 10,000 to 30,000 copies/mL (b) & 7 (21.2\%) & $28(22.1 \%)$ \\
\hline VL 30,000 to 100,000 copies $/ m L$ (b) & II (33.3\%) & 35 (27.5\%) \\
\hline$V L>100,000$ copies $/ m L$ (b) & $9(27.2 \%)$ & $56(44.1 \%)$ \\
\hline \multicolumn{3}{|l|}{ ART prior to HAART } \\
\hline \multicolumn{3}{|c|}{ HIV-infected children with previous ART (b) } \\
\hline Monotherapy & 15 (45.4\%) & 71 (55.9\%) \\
\hline Combined Therapy & $18(54.5 \%)$ & $99(77.9 \%)^{*}$ \\
\hline Monotherapy + Combined Therapy & $20(60.6 \%)$ & $110(86.6 \%)^{*}$ \\
\hline Time (months) with previous ART (a) & $25.9(0 ; 75.8)$ & $22.4(0 ; 114.1)$ \\
\hline Previous ART-protocol switches (a) & $2(0 ; 4)$ & $2(0 ; 5)$ \\
\hline
\end{tabular}

Values are expressed as: a) median (min; max), and b) absolute (percentage). VL: viral load; CDC = Center for Disease Control. VL: viral load. Differences between groups $(*: p<0.01)$. 
Table 2: Characteristics of antiretroviral treatment and virologic parameters of vertically HIV-I-infected children during follow-up.

\begin{tabular}{lcc}
\hline & Responders & Non-Responders \\
\hline HAART during follow-up & & \\
NNRTI or PI in first-line of HAART (b) & & $32(25.1 \%)$ \\
$\quad$ Ritonavir & $4(12.1 \%)$ & $12(9.4 \%)$ \\
Saquinavir & $6(18.2 \%)$ & $28(22.1 \%)$ \\
$\quad$ Indinavir & $8(24.2 \%)$ & $44(34.6 \%)$ \\
$\quad$ Nelfinavir & $10(30.3 \%)$ & $5(3.9 \%)$ \\
$\quad$ Amprenavir & $3(9.1 \%)$ & $6(4.7 \%)$ \\
Nevirapina & $0(0 \%)$ & $10(7.8 \%)$ \\
Efavirenz & $6(18.1 \%)$ & $1(0 ; 11) *$ \\
ART-protocols switches (a) & $1(0 ; 4)$ & $3(0 ; 12) *$ \\
Drugs switches (a) & $1(0 ; 7)$ & $61(48 \%) *$ \\
Adherence $>95 \%$ (b) & $30(90.9 \%)$ & $21(3 ; 48)$ \\
VL tests & & $3(0 ; 23) *$ \\
Total VL tests (a) & $20(6 ; 34)$ & $29.4(0.9 ; 59.8) *$ \\
Number of tests with VL $\leq 400$ copies $/ \mathrm{mL}$ (a) & $15(5 ; 28)$ & $57.5(31.8 ; 60) *$ \\
Time to first uVL measure (a) & $3.7(0.2 ; 12)$ & \\
Time to last uVL measure (a) & $49.8(16.1 ; 59.6)$ & \\
\hline
\end{tabular}

Values are expressed as: a) median (min; max), and b) absolute (percentage). ART: antiretroviral therapy; VL: viral load; PI: protease inhibitor; NNRTI. Differences between groups (*: $p<0.01)$.

trician by examination of the dose taken by each child and through interviews with his parents or tutors.

\section{Response to long-term HAART}

A completed long-term virological response to HAART was defined when HIV-child achieved undetectable VL $(\leq 400$ copies $/ \mathrm{ml})$ in the first 12 months of therapy and maintained that level during at least 12 months. Thus, HIV-infected children were divided into two groups according to responses to long-term HAART:

a) Responders group

33 HIV-infected children with a full long-term virological response during at least 12 months. Detectable VL during a 12 months period, even if a small "blip", disqualified children from being included in the Responders group. Moreover, 29 of 33 had full long-term virological response during at least 24 months, and 25 of 33 had full long-term virological response during at least 36 months.

b) Non-Responders group

127 HIV-infected children with persistently VL despite HAART (VL $\geq 400$ copies/ml during follow-up). These HIV-infected children had prolonged virological failure in spite of ART switches.

\section{HIV-I infection laboratory markers}

T-lymphocyte subsets in peripheral blood were quantified by flow cytometry (FACScan, Becton-Dickinson Immunocytometry Systems, San Jose, CA, USA). VL was measured in $200 \mu$ l plasma samples using a quantitative assay (Amplicor monitor, Roche Diagnostic Systems, Brandenburg, NJ, USA).

\section{Statistical analysis}

We analyzed the CD4+ at $0,12,24,36$, and 48 months follow-up of children on HAART grouped according to response to long-term virological suppression with a General Lineal Model (GLM) Univariate (regression analysis) adjusted by baseline characteristics (age, sex, ART-naïve, CD4+, and VL). In addition, we analyzed immunological response to HAART in HIV-infected children $\left(\mathrm{CD} 4{ }^{+}>25 \%\right.$ at $12,24,36,48$ months follow-up) by logistic regression.

\section{Results}

At baseline (before starting HAART), the two groups had similar age, percentage in clinical category $\mathrm{C}$, levels of $\mathrm{CD}^{+}$and CD8+ T-cells, and VL (Table 1). However, the Non-Responders group had a higher percentage of the pre-treatment with ART.

During follow-up, one child progressed to AIDS and one child died. Moreover, the Non-Responders group presented a significantly higher number of ART switches, higher number of different drugs used in ART than children of the Responders group $(\mathrm{p} \leq 0.05)$ (Table 1$)$.

Long-term viral load suppression was achieved in only about $20 \%$ of followed children. This low figure is mostly related to poor adherence by the non-responders group ( $48 \%$ vs $91 \%$ in responders) (Table 1 ). There were not significant differences in adherence according to hospital and region involved.

Table 2 shows the first line HAART schemes. We did not find significant differences in PI used in first line HAART between groups. Moreover, there were 3320 VL assays per- 


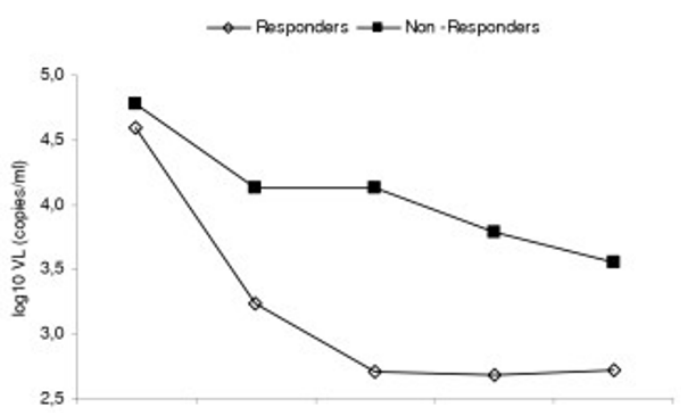

B

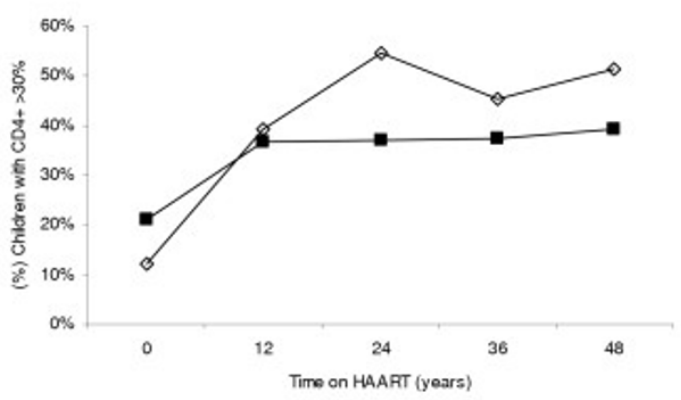

Figure I

Evolution of mean plasma $\log _{10} \mathrm{VL}(\mathrm{A})$ and percentage of HIV-infected children with $\mathrm{CD}^{+}>30 \%$ (B) grouped by longterm VL suppression (Responders vs. Non-Responders). ${ }^{\text {an: }}$ number of children in the Responders group. ${ }^{b} \mathrm{n}$ : number of children in the Non-Responders group. Differences between groups (*: $p<0.0 \mathrm{I})$.

formed on samples obtained from HIV-infected children during the 4 years of follow-up; 1054 (47.3\%) of those did not reach the lower limit of detection of 400 HIV-RNA copies/mL. The VL tests performed were similar for the two groups, but the Responders group had a higher number of tests with VL $\leq 400$ copies/ml. Moreover, the median of time between the first and last VL $\leq 400$ copies/ $\mathrm{ml}$ measurement was lower in the Responder group than the Non-responder group (Table 2). The Responders group had $\mathrm{uVL}$ after the $1^{\text {st }}$ year on HAART and the NonResponders group had a low decrease of VL during the 4 years of follow-up (Figure 1A). Furthermore, the Responders group had a higher percentage of children with CD4+ $>30 \%$ than the Non-Responders group after $1^{\text {st }}$ year on HAART (Figure 1B).

Table 3 shows the mean of $\% \mathrm{CD}^{+}$and percentage of HIVinfected children with $\mathrm{CD} 4^{+} \geq 25 \%$ during the 4 years of follow-up stratified by virological response to HAART. We observed an initial and significant fast increase in CD4 ${ }^{+}$ counts from baseline to 12 months on HAART in both groups $(\mathrm{p}<0.01)$. Interestingly, there were children on HAART with sustained CD4+ increases but with detectable VL. Non-Responders group was sustained CD4+ increases and most of theses HIV-infected children maintained high CD4+ level counts $(\geq 25 \%)$. The Non-Responders group also reached a plateau between $26 \%$ and $27 \%$ $\mathrm{CD} 4^{+}$at 12 months of follow-up that remained stable during the following 3 years (Table 3 ). However, the Responders group reached a plateau between $30 \%$ and $32 \% \mathrm{CD}^{+}$ at 24, 36 and 48 months of follow-up. We found that the Responders group had higher $\mathrm{CD}^{+}$count values and a higher percentage of children with $\mathrm{CD}^{+} \geq 25 \%$ than the Non-Responders group ( $\mathrm{p}<0.05)$ after month 12 (Table 3$)$.

\section{Discussion}

The introduction of HAART represented a major breakthrough in the therapeutics of HIV-infected patients. However, the overall effectiveness of long-term HAART on HIV-infected children has been scarcely studied. Thus, to date, few studies reflect the evolution of a large cohort of HIV-infected children throughout long-term HAART [6]. To analyze this, we recruited a large group of HIV-infected children starting HAART and tracked their progress for 4 years. Our retrospective longitudinal study provides evi-

Table 3: Summary of $\% \mathrm{CD4}^{+} \mathrm{T}$-cell and percentages of HIV-infected children having $\mathrm{CD4}^{+} \geq 25 \%$ at $0,12,24,36$, and 48 months of follow-up stratified by long-term virological response to HAART. The groups were compared by General Lineal Model and Logistic Regression analysis adjusted.

\begin{tabular}{|c|c|c|c|c|c|c|c|c|c|}
\hline \multirow[b]{2}{*}{ Follow-up } & \multicolumn{5}{|c|}{ CD4+ ${ }^{+}$-cells (\%) } & \multicolumn{4}{|c|}{ Percentage of children with CD4 ${ }^{+} \geq 25 \%$} \\
\hline & n. & Responders & n. & $\begin{array}{c}\text { Non- } \\
\text { Responders }\end{array}$ & $\boldsymbol{p}$ & Responders & $\begin{array}{c}\text { Non- } \\
\text { Responders }\end{array}$ & OR (C195\%) & $\boldsymbol{p}$ \\
\hline 0 months & 33 & $16.4 \pm 1.9$ & 123 & $18.7 \pm 1.2$ & 0.190 & $24.2 \%$ & $31.4 \%$ & $0.6(0.2 ; 1.6)$ & 0.372 \\
\hline 12 months & 31 & $27.5 \pm 1.7$ & $|2|$ & $26.2 \pm 0.2$ & 0.145 & $64.5 \%$ & $53.7 \%$ & $2.6(0.9 ; 7.3)$ & 0.071 \\
\hline 24 months & 31 & $29.5 \pm 1.3$ & 115 & $27.2 \pm 0.9$ & 0.010 & $70.9 \%$ & $57.4 \%$ & $3.1(1.1 ; 8.6)$ & 0.031 \\
\hline 36 months & 30 & $31 \pm 1.2$ & 109 & $27.7 \pm 0.9$ & 0.005 & $83.3 \%$ & $62.3 \%$ & $4.4(1.4 ; 13.6)$ & 0.009 \\
\hline 48 months & 28 & $32.1 \pm 1.3$ & 97 & $27.9 \pm 1$ & 0.004 & $85.7 \%$ & $62.8 \%$ & $5.4(1.5 ; 18.9)$ & 0.008 \\
\hline
\end{tabular}

OR: odd ratio; $\mathrm{Cl} 95 \%$ : confidence interval of $95 \%$; : level of significance. 
dence from current clinical practice that HAART always show long-term sustained uVL only in a low proportion of children (20.6\%) just as it has previously been showing in published results in adults [7].

$\mathrm{CD} 4{ }^{+}$recovery despite virological failure has been referred to as discordant responses and this phenomenon has been observed in children [8]. However, in children on HAART, levels of $\mathrm{CD}^{+}{ }^{+}$recovery were not comparable for virological responders and non-responders, indicating that $\mathrm{CD} 4+$ recovery during virological suppression is more profound than during virological failure [8]. This may reflect the inhibitory effect of HIV on thymic function since a marked decrease or suppression in VL is necessary to allow the thymus to replenish the $\mathrm{CD} 4{ }^{+} \mathrm{T}$-cells. Moreover, CD4+ T-cells are productively infected by HIV, undergoing apoptosis induced by abnormal cellular activation when the VL is not controlled [9].

In children with virological failure and good immunological and clinical outcomes observations have that virological failure does not always equal clinical failure $[10,11]$. Others authors have suggested that in children VL suppression may not be the best way to clinically evaluate ART success as it seem to be for HIV-infected adults [7]. Addition, HIV-infected children on HAART usually have higher VL and lower virological response rates than adults [12]. Thus, maintaining constant or improving $\mathrm{CD} 4^{+}$ counts may represent alternative indices of ART success in children [13]. We found an increase of $\mathrm{CD} 4^{+}$counts in the Responders and the Non-Responders groups. This indicates that VL suppression was not indispensable to the recovery of the immune system in vertically HIV-infected children. Moreover, only one Non-Responders child died during follow-up and another evolved to AIDS. We carried out indirect measurement between responders and nonresponders (hospitalization rates, weight/height growth curves, and numbers of opportunistic infections), and we found an improvement in these indices but not find differences between groups (data not shown). Therefore, virological failure does not always equal clinical failure and virological suppression does not necessarily mean proper function. However, long-term suppression of VL allowed higher values of $\mathrm{CD} 4^{+}$counts.

High VL is associated with immune system activation which is used as a predictive marker of virologic failure $[14,15]$. Moreover, viral suppression is a powerful predictor of $\mathrm{CD}^{+}$increase [16]. About $30 \%$ of HIV-infected adults receiving HAART exhibit a sustained $\mathrm{CD} 4^{+}$increase despite therapy failure, or they have persistently low $\mathrm{CD} 4{ }^{+}$ counts despite a significant decrease in VL [17]. In this study, approximately $30 \%$ of HIV-infected children also had an increase of $\mathrm{CD}^{+}$to a level $\geq 25 \%$ at 24 (57.39\%-
$35.52 \%), \quad 36(62.38 \%-35.52 \%)$, and $48 \quad(62.88 \%-$ $35.52 \%)$ months.

The capacity for $\mathrm{CD}^{+}$regeneration during long-term HAART has not been well defined. In our study, children reached a plateau in $\mathrm{CD} 4{ }^{+}$cell after 2 years on HAART just as others authors have published results in adults $[18,19]$. Moreover, Hunt et al. present strong evidence that $\mathrm{CD} 4^{+}$ counts continue to increase up to 4 years after HAART [20]. However, the rate of $\mathrm{CD} 4^{+}$recovery in adults is slow and a steady state is not usually reached after 4 years most likely because the adult thymus is less functional than in children [21].

A limitation of our study was that we did not have virologic resistance data previous to HAART and during follow-up. Increasingly many clinicians and investigators are describing multi-drug resistant HIV among children who are extensively HAART experienced [22]. Moreover, high baseline VL and substantial but imperfect levels of adherence were associated with HIV-resistance [23] and may facilitate an earlier virological failure [22]. Therefore, adherence to medication is extremely important and may have a significant, effect unaccounted for in the interpretation of our results. All efforts were made by health personnel to improve adherence in each child. Traditionally, children's adherence to ART has been limited, even though response to therapy has been shown to be highly dependent on the patient's adherence $[24,25]$. In this study, the adherence to ART was not strictly monitored, as opposed to standard clinical trials. We also found that adherence to ART was the most important variable associated with long-term VL suppression (data not shown). However, therapy adherence is almost impossible to reliably measure, and accurately reproduce in a long-term dynamic cohort [7]. This low adherence in the NonResponders group is not related to the level of training received by the health personal who provided the medical care. Furthermore, the number of doctor visits was similar in both groups of children, but the Responders group had a higher number of tests with VL $\leq 400$ copies/mL and a lower time with the first uVL measurement than the NonResponders group.

\section{Conclusion}

In conclusion, long-term VL suppression induces large beneficial effects in immunological responses. However, it is not indispensable to recover $\mathrm{CD} 4^{+}$counts (levels).

\section{Competing interests}

The author(s) declare that they have no competing interests. 


\section{Authors' contributions}

- Salvador Resino had primary responsibility for protocol development, patient screening, enrollment, outcome assessment, preliminary data analysis, and contributed to the writing of the manuscript.

- Rosa Resino had primary responsibility for the collecting and recording data, and contributed to the writing of the manuscript.

- José María Bellón participated in analytic framework for the study, and contributed to the writing of the manuscript.

- Pediatricians: Juan Antonio León, Pablo Matín Fontelos, José Tomás Ramos, $M^{a}$ Dolores Gurbindo Gutiérrez, $M^{a}$ Isabel de José, and Luis Ciria were responsible for patient screening, and contributed to the writing of the manuscript.

- Ma Angeles Muñoz-Fernández supervised the design and execution of the study, the final data analyses, and the writing of the manuscript.

\section{Acknowledgements}

Financial Support: Fundación para la Investigación y la Prevención del SIDA en España (FIPSE) (grant I2456/03) Fundación para la Investigación Sanitaria (FIS) del Ministerio de Sanidad y Consumo (PI040883, PI052479, PI052472, PI0524I I), Plan Nacional de Salud (SAF 2003-09209, SAF-200406778), Red Temática Cooperativa de investigación en SIDA (RIS G03/

173) of FIS, and Red Temática Cooperativa de investigación en Genética (RIG C03/07) of FIS.

Salvador Resino and Jose María Bellón are supported by a grant of FIS (grant CP04/00090, $01 / A 016$ respectively).

Participating hospitals and sites

\section{MADRID:}

Hospital Universitario "I2 Octubre": J.T. Ramos, P. Carreño, J. Ruiz, J. Clemente.

Hospital General Universitario "Gregorio Marañón": S. Resino, A. AlvaroMeca, R. Resino, J.M. Bellón, M.D. Gurbindo, M.L. Navarro, M.A. MuñozFernández.

Hospital Universitario "La Paz": M.I. Isabel de José.

Hospital Universitario "Carlos III": P. Martín-Fontelos, M.J. Mellado, J. Villota.

\section{SEVILLE:}

Hospital Universitario "Virgen del Rocio": J.A. León Leal.

\section{References}

I. Resino S, Bellón JM, Gurbindo D, Ramos JT, León JA, Mellado MJ, Muñoz-Fernández MA: Viral Load and CD4+ T-Cells Response to HAART in HIV-Infected Children: a Observational Study. Clin Infect Dis 2003, 37:1216-1225.

2. Borkowsky W, Stanley K, Douglas SD, Lee S, Wiznia A, Pelton S, Yogev R, Mclntosh K, Nachman S: Immunologic response to combination nucleoside analogue plus protease inhibitor therapy in stable antiretroviral therapy-experienced human immunodeficiency virus-infected children. J Infect Dis 2000, 182:96-103.

3. Resino S, Bellón JM, Resino R, Navarro ML, Ramos JT, Mellado MJ, de Jose MI, Muñoz-Fernández MA: Extensive implementation of highly active antiretroviral therapy shows great effectiveness on the survival and surrogate markers in vertically HIVinfected children. Clin Infect Dis 2004, 38:1605-1612.

4. Wiznia A, Stanley K, Krogstad P, Johnson G, Lee S, McNamara J, Moye J, Jackson JB, Mendez H, Aguayo R, Dieudonne A, Kovacs A, Bamji M, Abrams E, Rana S, Sever J, Nachman S: Combination nucleoside analog reverse transcriptase inhibitor(s) plus nevirapine, nelfinavir, or ritonavir in stable antiretroviral therapy- experienced HIV-infected children: week 24 results of a randomized controlled trial--PACTG 377. Pediatric AIDS Clinical Trials Group 377 Study Team. AIDS Res Hum Retroviruses 2000, 16:1113-II21.

5. van Rossum AM, Geelen SP, Hartwig NG, Wolfs TF, Weemaes CM, Scherpbier HJ, van Lochem EG, Hop WC, Schutten M, Osterhaus AD, Burger DM, de Groot R: Results of 2 years of treatment with protease-inhibitor--containing antiretroviral therapy in dutch children infected with human immunodeficiency virus type I. Clin Infect Dis 2002, 34:1008-1016.

6. Soh CH, Oleske JM, Brady MT, Spector SA, Borkowsky W, Burchett SK, Foca MD, Handelsman E, Jimenez E, Dankner WM, Hughes MD: Long-term effects of protease-inhibitor-based combination therapy on CD4 T-cell recovery in HIV-I-infected children and adolescents. Lancet 2003, 362:2045-205I.

7. Holmberg SD, Hamburger ME, Moorman AC, Wood KC, Palella FJ]: Factors associated with maintenance of long-term plasma human immunodeficiency virus RNA suppression. Clin Infect Dis 2003, 37:702-707.

8. Resino S, Galan I, Perez A, Leon JA, Seoane E, Gurbindo D, MuñozFernández MA: HIV-infected children with moderate-severe immune-suppression: changes in the immune system after highly active antiretroviral therapy. Clin Exp Immunol 2004, 137:570-577.

9. Douek DC, Picker LJ, Koup RA: T cell dynamics in HIV-I infection. Annu Rev Immunol 2003, $21: 265-304$.

10. Chiappini E, Galli L, Zazzi M, de Martino M: Immunological recovery despite virological failure is independent of human immunodeficiency virus-type I resistant mutants in children receiving highly active antiretroviral therapy. J Med Virol 2003 , 70:506-512.

II. Peruzzi M, Azzari C, Galli L, Vierucci A, De Martino M: Highly active antiretroviral therapy restores in vitro mitogen and antigenspecific T-lymphocyte responses in HIV-I perinatally infected children despite virological failure. Clin Exp Immunol 2002, | 28:365-37|.

12. Melvin AJ, Rodrigo AG, Mohan KM, Lewis PA, Manns-Arcuino L, Coombs RW, Mullins JI, Frenkel LM: HIV-I dynamics in children. J Acquir Immune Defic Syndr Hum Retrovirol 1999, 20:508-5 I3.

13. Deeks SG, Barbour JD, Grant RM, Martin JN: Duration and predictors of CD4 T-cell gains in patients who continue combination therapy despite detectable plasma viremia. AIDS 2002, 16:201-207.

14. Resino S, Bellón JM, Ramos JT, Gonzalez-Rivera M, de José MI, González MI, Gurbindo D, Mellado MJ, Cabrero E, Muñoz-Fernández MA: Positive virologic outcome after lopinavir/ritonavir salvage therapy in protease inhibitor-experienced HIV-Iinfected children. A prospective cohort study. J Antimicrob Chemother 2004, 54:92I-93I.

15. Paul ME, Mao C, Charurat M, Serchuck L, Foca M, Hayani K, Handelsman EL, Diaz C, Mclntosh K, Shearer WT: Predictors of immunologic long-term nonprogression in HIV-infected children: Implications for initiating therapy. J Allergy Clin Immunol 2005, I I 5:848-855.

16. Koletar SL, Williams PL, Wu J, McCutchan JA, Cohn SE, Murphy RL, Lederman HM, Currier JS: Long-term follow-up of HIV-infected individuals who have significant increases in CD4+ cell 
counts during antiretroviral therapy. Clin Infect Dis 2004, 39:1500-1506.

17. Deeks SG, Barbour JD, Martin JN, Swanson MS, Grant RM: Sustained CD4+ $T$ cell response after virologic failure of protease inhibitor-based regimens in patients with human immunodeficiency virus infection. J Infect Dis 2000, | 81:946-953.

18. Kaufmann GR, Bloch M, Finlayson R, Zaunders J, Smith D, Cooper DA: The extent of HIV-I-related immunodeficiency and age predict the long- term CD4 T lymphocyte response to potent antiretroviral therapy. Aids 2002, 16:359-367.

19. Tarwater PM, Margolick JB, Jin J, Phair JP, Detels R, Rinaldo C, Giorgi J, Munoz A: Increase and plateau of CD4 T-cell counts in the $3(1 / 2)$ years after initiation of potent antiretroviral therapy. J Acquir Immune Defic Syndr 200I, 27: I68-I75.

20. Hunt PW, Deeks SG, Rodriguez B, Valdez H, Shade SB, Abrams DI, Kitahata MM, Krone M, Neilands TB, Brand RJ, Lederman MM, Martin JN: Continued CD4 cell count increases in HIV-infected adults experiencing 4 years of viral suppression on antiretroviral therapy. Aids 2003, 17:1907-1915.

21. Franco JM, Leon-Leal JA, Leal M, Cano-Rodriguez A, Pineda JA, Macias J, Rubio A, Rey C, Sanchez B, Lissen E: CD4+ and CD8+ T lymphocyte regeneration after anti-retroviral therapy in HIV-Iinfected children and adult patients. Clin Exp Immunol 2000, I 1 9:493-498.

22. Jimenez JL, Resino S, Martinez-Colom A, Bellon JM, Munoz-Fernandez MA: Mutations at codons 54 and 82 of HIV protease predict virological response of HIV-infected children on salvage lopinavir/ritonavir therapy. J Antimicrob Chemother 2005 in press.

23. Harrigan PR, Hogg RS, Dong WW, Yip B, Wynhoven B, Woodward J, Brumme CJ, Brumme ZL, Mo T, Alexander CS, Montaner JS: Predictors of HIV drug-resistance mutations in a large antiretroviral-naive cohort initiating triple antiretroviral therapy. J Infect Dis 2005, 191:339-347.

24. Watson DC, Farley J]: Efficacy of and adherence to highly active antiretroviral therapy in children infected with human immunodeficiency virus type I. Pediatr Infect Dis J 1999, 18:682-689.

25. Reddington $C$, Cohen J, Baldillo A, Toye M, Smith D, Kneut C, Demaria A, Bertolli J, Hsu HW: Adherence to medication regimens among children with human immunodeficiency virus infection. Pediatr Infect Dis J 2000, 19: I |48-I I 53.

\section{Pre-publication history}

The pre-publication history for this paper can be accessed here:

http://www.biomedcentral.com/1471-2334/6/10/prepub

\section{Publish with Biomed Central and every scientist can read your work free of charge}

"BioMed Central will be the most significant development for disseminating the results of biomedical research in our lifetime. "

Sir Paul Nurse, Cancer Research UK

Your research papers will be:

- available free of charge to the entire biomedical community

- peer reviewed and published immediately upon acceptance

- cited in PubMed and archived on PubMed Central

- yours - you keep the copyright 